\title{
Comparative study of stability and half-life of enzymes and enzyme aggregates implemented in anaerobic biogas processes
}

\author{
Roman Binner • Veronika Menath • Harald Huber • \\ Michael Thomm • Franz Bischof • Doris Schmack • \\ Monika Reuter
}

Received: 21 September 2010 /Revised: 10 December 2010 /Accepted: 20 December 2010 /Published online: 25 January 2011

(C) Springer-Verlag 2011

\begin{abstract}
Anaerobic digestion of mainly energy crops gains more and more importance in developing a sustainable energy supply. Therefore, the optimization of gas yield plays a major role in specific research attempts and economical considerations. One possibility to increase natural polymer degradation and concomitantly energy efficiency is the addition of exoenzymes to biogas facilities to enforce the primary degradation steps for biogas production. Therefore, in the present study, the stability and activity of five externally added enzyme mixtures to anaerobic biogas processes were investigated. Protein assays using soluble fractions of different biogas plants incubated together with the enzyme mixtures revealed that, within about $10 \mathrm{~min}$, the externally added enzymes were mostly degraded. This very low stability in biogas reactors makes it unlikely that the addition of enzymes contributes significantly to degradation of macromolecules in the biogas process. Even the addition of protease inhibitors did not protect the added enzyme mixtures from degradation in most experiments. Furthermore, the influence of
\end{abstract}

\footnotetext{
R. Binner $\cdot$ D. Schmack $\cdot$ M. Reuter $(\varangle)$

Research and Development Department, Schmack Biogas GmbH, Bayernwerk 8,

92421 Schwandorf, Germany

e-mail: monika.reuter@schmack-biogas.com

V. Menath $\cdot$ H. Huber $\cdot$ M. Thomm

Department of Microbiology, University of Regensburg,

Universitätsstrasse 31,

93053 Regensburg, Germany

F. Bischof

Faculty of Mechanical Engineering/Environmental Engineering, University of Applied Sciences Amberg-Weiden,

Kaiser-Wilhelm-Ring 23,

92224 Amberg, Germany
}

added enzymes on the viscosity of the biomass was tested. Only a marginal effect was obtained, when applying a tenfold higher concentration of added enzymes as proposed for practical use. The same result was achieved when commercially available enzymes were added to technicalscale fermentations using corn silage as monosubstrate. Therefore, these studies did not provide evidence that the addition of external enzymes into anaerobic degradation systems increases the methane yield in biogas facilities.

Keywords Biogas · Fermentation · Enzyme - Anaerobic · Degradation

\section{Introduction}

Substitution of fossil fuels by renewable resources comes more and more into focus for the rapidly growing energy demand. On the one hand, most known conventional gas and oil reserves will possibly run out within the next decades and are partly located in politically unstable regions; on the other hand, pollution with atmospheredamaging greenhouse gases is a rising problem [1]. In 2008, the European Renewable Energy Council passed an EU directive with ambitious and engaging aims to substitute $20 \%$ of the world's energy demand by renewable energies [2]. Biogas plays a major role in regarding a replacement of fossil fuels for production of heat and power. It has been evaluated as one of the most efficient technologies, and it is most beneficial to the environment for bioenergy production [3]. Biogas technology in Germany played an increasingly important role within the last 9 years. The number of biogas plants rose from 2,010 plants in 2004 to 3,280 plants in 2006. Within this period of 
time, the installed electrical power nearly quadrupled from $247 \mathrm{MW}_{\mathrm{el}}$ (megawatt, electrical) to $950 \mathrm{MW}_{\mathrm{el}}$ [4]

However, biogas research is a relatively new field of investigation. Increasing the specific gas yield from organic dry matter is one of the most important tools to raise the efficiency of biogas plants. Different enzyme products are available on the market, which promise an increase in biogas yield during anaerobic fermentation. Biogas formation is a multiphase process, often conducted by microbial communities in a single reactor, involving the steps of hydrolysis, acidogenesis and acetogenesis, and finally methanogenesis, where methane is actually formed. In the first step, the hydrolysis, exoenzymes, which are produced by microorganisms, play a major role in degradation. Carbohydrates are degraded by cellulases into monosaccharides, disaccharides, and trisaccharides, proteins are decomposed by proteases and peptidases into amino acids, and lipids are catabolized by lipases into long-chain fatty acids and glycerol. Biological degradation of lignocellulosic material is usually facilitated by enzymes such as cellulases and hemicellulases, which are naturally produced by microorganisms growing in an anaerobic digester [5]. Previous observations in praxis tests have indicated that the addition of enzymes into anaerobic digesters using food processing waste as major substrate may result in an improved digestion: enhanced anaerobic digestion of citrus peels was observed with an enzyme solution from Aspergillus sp. A-1. The enzyme solution had cellulase and pectinase activities that allowed the anaerobic digester to operate at a higher organic loading rate [6]. In another study, wheat grains were pre-treated with Trizyme (cellulase, $\alpha$-amylase, and protease) prior to anaerobic digestion. An increase in methane production up to $7 \%$ to $14 \%$ was demonstrated [7]. Further studies showed that the addition of cellulase (Celluclast $200 \mathrm{~L}$ ) and $\beta$-glucosidase (Novozyme 188) to sewage sludge prior to anaerobic digestion resulted in an increase of biogas and methane yield by $12 \%$ and $15 \%$, respectively [8]. Pretreatment of sewage sludge with protease K (type XI, from Tritirachium album), thermolysin (type $\mathrm{X}$ from Bacillus thermoproteolyticus), trypsin (type XI, from bovine pancreas), and lysozyme (from chicken egg white) resulted in a $22 \%$ increase in soluble chemical oxygen demand after a 4.1-h treatment [9]. Rintala and Ahring [10] investigated the addition of Pulpzyme HA (xylanase and cellulase), Alcalase 2.5 LB (protease), and Resinase A 2X (lipase) to the anaerobic digestion of source-separated household solid waste. In batch treatments, enzymes were added individually or as a mixture, and the specific methane activity (SMA) was measured (defined as the slope of the cumulative methane production from the initial $20-30 \mathrm{~h}$ of digestion per volatile solids (VS) content of the inoculum). Only at a concentration of $0.5 \mathrm{ml} / \mathrm{kg}$ VS did protease preparation result in significantly higher (11\%) SMA. However, the authors reported no significant differences in biogas yield or volatile fatty acid (VFA) concentration in the reactor effluent between enzymetreated and non-enzyme-treated continuous digester systems [5]. As previously mentioned, reaction products such as VFA can accumulate in the biomass boundary layer and induce local $\mathrm{pH}$ values that inhibit the biogas production process, although this effect would not be detected in samples from bulk liquid [11]. Other studies onto enzyme mixtures of Trichoderma reesei showed that a detectable surplus in biogas yield can be detected. The increase in biogas production obtained in this trial ranged from $4 \%$ to $35 \%$ compared with the calculated biogas formation based on expected substrate conversion rates. An average increase of $18 \%$ was determined, and the confidence interval of the average ranged between $15 \%$ and $22 \%$. The observed variability between the results could be explained by the different operating conditions, different added substrates, and the varying standards of data recording in the various production plants [12]. Previous studies suggested that addition of exogenous enzymes can improve the performance of anaerobic digestion systems. However, enzyme activity can be affected by many factors including substrate, incubation time, system configuration, and environmental conditions (like temperature or $\mathrm{pH}$ value) [5]. Beyond that, there are further limiting and/or negative factors during the fermentation of agricultural sustainable raw material, which can influence the efficiency of enzyme employment on the one hand and/or even force back the effect towards the enzymatic treatment on the other hand. Many of these parameters varied significantly in all these published investigations. Therefore, the aim of this study was to obtain comparable and reliable results regarding the stability of externally added enzymes within the harsh environment of a biogas plant. Four different types of biogas plants with corn silage as single substrate (laboratory scale, 150- to 400-1 volume) were used to apply five different commercially available enzyme mixtures. We analyzed the amount of produced biogas, the degradation rate of the added enzymes, and in addition, the effect of external enzymes on the viscosity of the digester material.

\section{Material and methods}

\subsection{Laboratory digester}

The experiments were performed in lab-scale digesters with 150- to 400-1 volume (continuous-fermentation processes). The digesters exhibited different fermentation processes: a one-step process in the form of a plug flow fermenter (digester E2) or a pit storage (digester NG10) or a two-step fermentation process with two separate 
compartments for hydrolysis (digester EvaH) and methanogenesis (digester EvaM). Fermentations were carried out at $40^{\circ} \mathrm{C}(\mathrm{E} 2, \mathrm{EvaH}$, and $\mathrm{EvaM})$ or $50^{\circ} \mathrm{C}(\mathrm{NG} 10)$ to represent averaged modes of operation due to mesophilic or thermophilic conditions within biogas plants. The volume load was between 2.4 and $5.7 \mathrm{~kg}$ organic dry matter (oDM) corn silage per cubic meter and day. The dry matter (DM) and oDM content of the digestate varied from $6.8 \%$ to $11.2 \%$ and from $5.5 \%$ to $9.5 \%$, respectively. Enzymes were added daily to the fermenters (maximal amounts as suggested by the providers). The energy efficiency of the process was calculated as quotient of the caloric value of the produced gas per $24 \mathrm{~h}$ (methane and hydrogen) and the caloric value of the input material per $24 \mathrm{~h}$ (corn silage) in steady state (formula 1):

energy transfer $=\frac{\text { caloric value biogas }\left[\mathrm{kJ} / \mathrm{m}^{3} \text { day }\right]}{\text { caloric value input material }[\mathrm{kJ} / \mathrm{kg} \text { day }]}$

To estimate the maximal gas yield achievable, batch fermentation tests were performed for at least 3 months until no gas was produced any more. This corresponds to the amounts of gas yield, which are indicated in Handreichung Biogas [13].

\subsection{Chemo-physical tests}

The DM content was determined in percent of the original substance according to DIN EN 12880 (S2a). Ash and $\mathrm{oDM}$ were determined in percent of the original substance according to DIN EN 12879 (S3a). The $\mathrm{pH}$ value was measured according to DIN EN 12176 (S5), and COD was identified in milligram per liter after DIN 38414, part 9. Total volatile fatty acids including acetate, propionate, isobutyrate, butyrate, iso-valerate, and valerate were determined in milligram per kilogram of the original substance after a domestic accredited method. The concentrations of methane, oxygen, hydrogen sulfide, and hydrogen in the biogas produced were quantitatively measured using an AWITE gas analyzer.

A change in viscosity could be detected within enzyme-treated digester material by using a simple complementary analysis of viscosity. Raw sample material from the four digesters (treated and untreated with enzymes, incubation time $14 \mathrm{~h}$ ) was applied separately onto a small inclined metal ramp (angle $38^{\circ}$ ), and the propagation after $15 \mathrm{~min}$ was determined. Enzymes were added according to the manufacturers' information. Furthermore, the dosage of the enzymes was increased tenfold to obtain measurable effects within the shortest possible time and in total. The tests were carried out in duplicates.

\subsection{Enzymes and additional substances}

Five different enzymes and enzyme mixtures were tested: pure cellulase (Sigma Aldrich) and four enzyme mixtures ("Biogasverstärker," "MethaPlus," "Viscozyme," and "Optimase") from different providers (Bioreact, Biopract, Novozymes, and Schmack Biogas, respectively). All mixtures were tested for their protein content [14] and in viscosity tests. Two of them were tested in lab-scale continuous fermentations: Optimase (Schmack Biogas AG), $2 \mathrm{ml}$ enzyme mixture per cubic meter and day; Biogasverstärker (Bioreact), $0.8 \mathrm{~g} /$ $\mathrm{m}^{3}$ day ${ }^{-1}$. In addition, both mixtures were tested in tenfold concentration. For proteinase inhibition, phenylmethylsulfonyl fluoride (PMSF, Sigma Aldrich) or a proteinase inhibitor cocktail (protease inhibitor cocktail M221, Amresco) was added to the enzyme solutions during the protein assays according to the manufacturer's recommendation.

\subsection{Protein assays}

Digester material $(50 \mathrm{ml})$ was stored on ice immediately after sampling, and if desired, proteinase inhibitors were added. The material was centrifuged two times at $4{ }^{\circ} \mathrm{C}$ (Sorvall RC6, rotor SS34) at 20,000 rpm for $30 \mathrm{~min}$ to remove fibers and inorganic, insoluble components. The components of the supernatant were concentrated in an ultracentrifuge (Beckmann, rotor SW60, $20 \mathrm{~min}$, $48,000 \mathrm{rpm}$ ), resulting in a fraction which contained almost exclusively extracellular enzymes that catalyze the first steps of microbial anaerobic conversion. Protein concentrations were determined by using a Bradford test [14] slightly modified: incubation time of $30 \mathrm{~min}$ (due to incomplete reactions at shorter incubation times). For the protein assay, 1.0 to $1.5 \mu \mathrm{g}$ of the precipitates of the ultracentrifuge treatment was used. Sodium dodecyl sulfate-polyacrylamide gel electrophoresis (SDS-PAGE) was performed as described by Schägger and Jagow [15] using the pre-stained PageRuler ${ }^{\mathrm{TM}}$ (Fermentas Life Science) as marker.

For degradation assays, $1.0 \mu \mathrm{g}$ of each enzyme mixture was added to the supernatant of the four lab-scale digesters (containing the natural extracellular enzyme mixture) and was incubated for 3,15 , and $60 \mathrm{~min}$ at the same temperature which was used in the fermentation process $\left(40^{\circ} \mathrm{C}\right.$ or $\left.50^{\circ} \mathrm{C}\right)$. Samples were stored on ice and mixed with SDS-containing sample buffer immediately and applied to SDS-PAGE.

To measure the decrease in protein content, Bradford tests were performed with the supernatant of the digester material (Sorvall RC6, rotor SS34, 10,000 rpm for $45 \mathrm{~min}$ ). For the test, $0.5 \mathrm{ml}$ of the above-described 
Fig. 1 Continuous fermentation process (digester E2) with corn silage without and with the enzyme mixture Biogasverstärker at a volume load rate of $3 \mathrm{~kg} \mathrm{oDM} / \mathrm{m}^{3}$ day $^{-1}$. a Specific gas yield per day in $\mathrm{Nl}$ per kilogram oDM (grey with $x$ ); averaged gas yield for 6 days (grey dotted); theoretically expected amount $(663 \mathrm{Nl} / \mathrm{kg}$ oDM) (black); produced biogas per digester volume $(1 / 1 \times d)$ (dotted dark grey); averaged produced biogas for 6 days (1/1) (dashed dark grey). b $\mathrm{pH}$ value (grey with squares); concentration of fatty acids: acetic acid equivalent (dark grey with $x$ ); acetic acid (grey). (VFA volatile fatty acids). $\mathbf{c}$ Trends of DM (light grey with $x$ ); $\mathrm{oDM}$ (dashed light grey); temperature (grey with dots); viscosity (grey with squares). In all figures, the dark triangles on the $x$-axis indicate addition of enzymes once a day
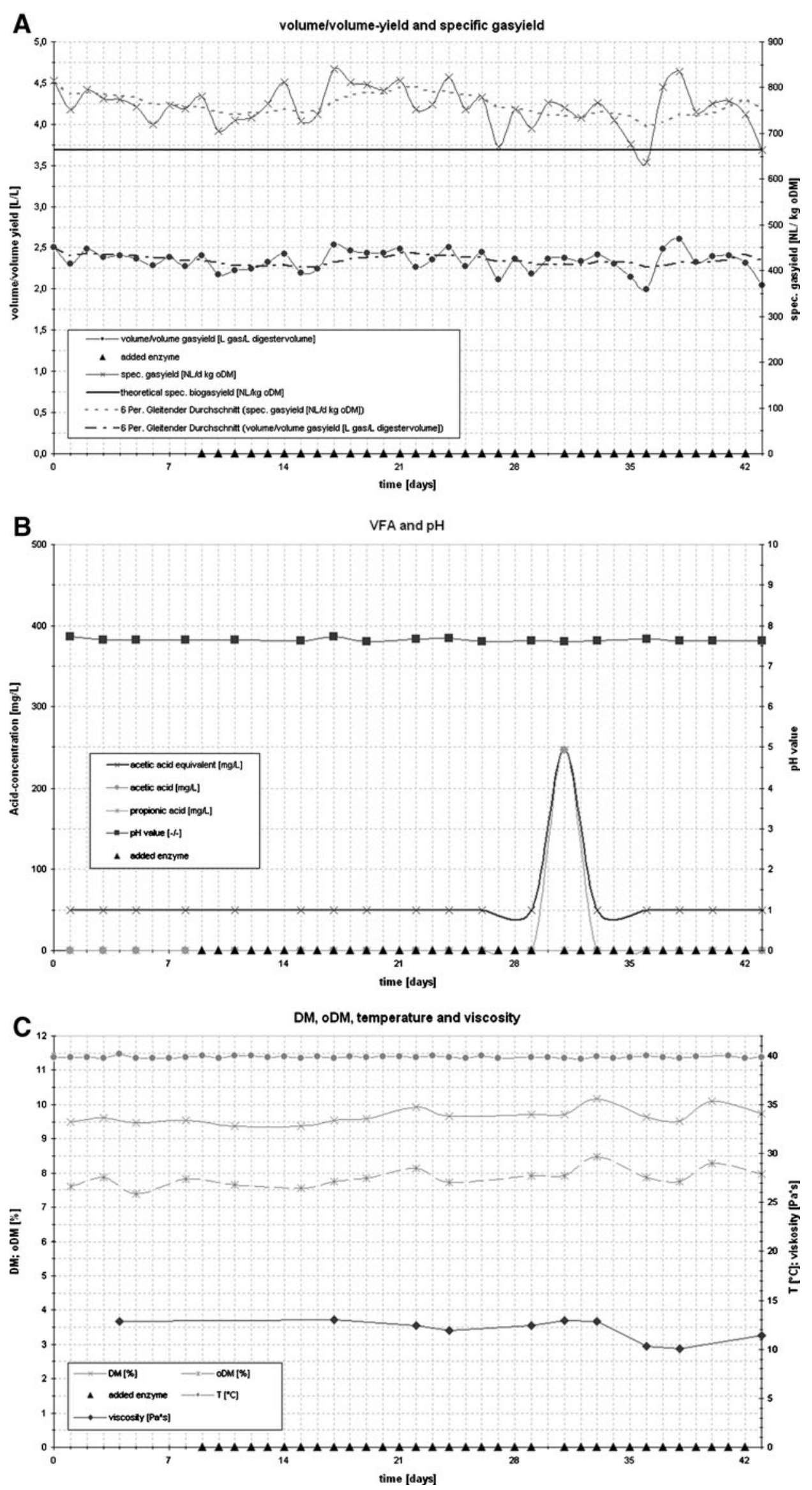

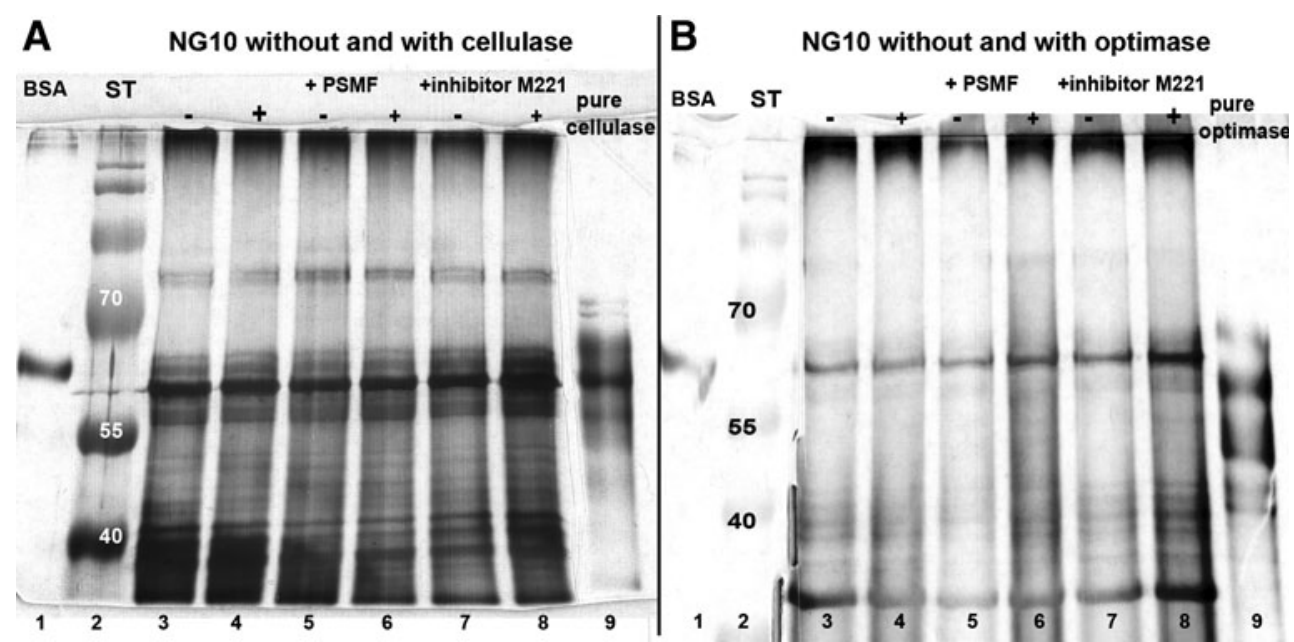

Fig. 2 Electrophoretic separation of treated material from digester NG10 (pit storage) without $(-)$ and with $(+)$ treatment of cellulase (a) or Optimase (b); All samples were incubated for $1 \mathrm{~h}$ at the digester temperature $\left(\mathrm{NG} 10=50^{\circ} \mathrm{C}\right)$. BSA (control protein) lanes 1 ; molecular weight marker, lanes 2; lanes 3 and 4, untreated extracellular enzymes from digester without and with cellulase $(0.5 \mu \mathrm{g})$ (a) or Optimase

exoenzyme preparations with a protein concentration of $0.3 \mathrm{mg} / \mathrm{ml}$ (digester NG10), $1.0 \mathrm{mg} / \mathrm{ml}$ (digester EvaM), $1.3 \mathrm{mg} / \mathrm{ml}$ (digester EvaH), and $2.7 \mathrm{mg} / \mathrm{ml}$ (digester E2) was mixed with $0.5 \mathrm{ml}$ of the enzyme mixtures: Cellulase (Sigma Aldrich) $5 \mathrm{mg} / \mathrm{ml}$, Optimase (Schmack Biogas) $6 \mathrm{mg} / \mathrm{ml}$, Biogasverstärker (Bioreact) $5.4 \mathrm{mg} / \mathrm{ml}$, MethaPlus (Biopract) $3.3 \mathrm{mg} / \mathrm{ml}$, and Viscozyme (Novozymes) $2.6 \mathrm{mg} / \mathrm{ml}$. As a negative control, $0.5 \mathrm{ml}$ of sterile water was added instead of digester material. The incubation times for all tests were $0,1,3$, and $10 \mathrm{~min}$.
$(1 \mu \mathrm{g})(\mathbf{b})$; lanes 5 and 6 , identical samples as in lanes 3 and 4 with the addition of PMSF $(0.3 \mu \mathrm{g})$; lanes 7 and 8 , material from lanes 3 and 4 treated with proteinase inhibitor cocktail "M221"; lanes 9, pure cellulase/Optimase in the same concentration as used for samples in lanes 4,6 , and 8

\section{Results}

3.1 Continuous-fermentation tests with and without enzymes

Corn silage monofermentation was performed in four lab-scale fermenters in the beginning without additive and afterwards for 9 days with addition of the enzyme mixture Biogasverstärker in amounts according to the provider's suggestions (Fig. 1). The loading rate was kept stable at $3.0 \mathrm{~kg} \mathrm{oDM} / \mathrm{m}^{3} \mathrm{day}^{-1}$. No additional gas yield

Table 1 Degradation of added enzymes in different digester materials

\begin{tabular}{|c|c|c|c|c|c|c|}
\hline Digester & $\begin{array}{l}\text { Product } \\
\text { Applied amount }(\mu \mathrm{g}) \\
\text { Incubation time [min] } \\
\text { Variation }\end{array}$ & $\begin{array}{l}\text { Cellulase } \\
1.5 \\
60\end{array}$ & $\begin{array}{l}\text { Optimase } \\
1.0 \\
60\end{array}$ & $\begin{array}{l}\text { Biogasverstärker } \\
0.5 \\
60\end{array}$ & $\begin{array}{l}\text { MethaPlus } \\
1.0 \\
60\end{array}$ & $\begin{array}{l}\text { Viscozym } \\
1.0 \\
60\end{array}$ \\
\hline \multirow[t]{3}{*}{ E2 } & Added enzymes & + & $+/-$ & $+/-$ & $+/-$ & + \\
\hline & $+\mathrm{PMSF}$ & + & $+/-$ & $+/-$ & $+/-$ & + \\
\hline & +inhib. C. M221 & + & $+/-$ & $+/-$ & $+/-$ & + \\
\hline \multirow[t]{3}{*}{ EvaH } & Added enzymes & + & $+/-$ & + & 0 & $+/-$ \\
\hline & $+\mathrm{PMSF}$ & + & $+/-$ & + & 0 & $+/-$ \\
\hline & +inhib. C. M221 & + & $+/-$ & + & 0 & $+/-$ \\
\hline \multirow[t]{3}{*}{ EvaM } & Added enzymes & + & $+/-$ & $+/-$ & 0 & $+/-$ \\
\hline & $+\mathrm{PMSF}$ & + & $+/-$ & $+/-$ & 0 & $+/-$ \\
\hline & +inhib. C. M221 & + & $+/-$ & $+/-$ & 0 & $+/-$ \\
\hline \multirow[t]{3}{*}{ NG10 } & Added enzymes & + & + & + & $+/-$ & + \\
\hline & $+\mathrm{PMSF}$ & + & + & + & $+/-$ & + \\
\hline & +inhib. C. M221 & + & + & + & $+/-$ & + \\
\hline
\end{tabular}

- complete degradation, 0 overlapping bands with extracellular enzymes, $+/-$ partly degraded 
could be measured after adding Biogasverstärker (Fig. 1a), and no change in VFA and $\mathrm{pH}$ value could be observed (Fig. 1b). Only on day 31 of the experiment was a higher concentration of acetic acid detected, which however disappeared during the next days (Fig. 1b). A slight increase of DM and oDM could be observed during the experiment (Fig. 1c), while a marginal decrease in viscosity was noticed after the addition of enzymes. The energy yield of this process, compared with that of a process without addition of enzymes, did not increase. A process without additives showed an energy efficiency of $74 \%$ (arithmetic average of three fermentation processes at $40^{\circ} \mathrm{C}$ for at least 3 months), a process with addition of the enzyme mixture Optimase resulted in $72 \%$ energy efficiency (two fermentations at $40^{\circ} \mathrm{C}$ for 3 months, data not shown), and a process with addition of the mixture Biogasverstärker also revealed an efficiency of about $72 \%$ (two fermentations at $40^{\circ} \mathrm{C}$ for 3 months, data not shown).

\subsection{Stability of enzymes}

To illustrate a typical experiment, the stability of the cellulase (Fig. 2a) and the enzyme mixture Optimase (Fig. 2b) as additive to material from the digester NG10, after an incubation time of $1 \mathrm{~h}$ at $50^{\circ} \mathrm{C}$, was analyzed by SDS-PAGE and silver staining. The enzyme fraction of the cellulase is composed of two polypeptides of about $70 \mathrm{kDa}$, while the enzyme mixture Optimase consists of several polypeptides of about 40 to $55 \mathrm{kDa}$. In this experiment, both enzyme mixtures were completely degraded (Fig. 2a).
Table 1 summarizes the results of all tested additives and digesters. In some cases (EvaH and EvaM with MethaPlus), the degradation of the added enzyme mixtures could not be determined by SDS-PAGE due to the presence of protein bands with identical apparent molecular weights in the digester supernatant. Whenever the additives could be analyzed by SDS-PAGE, the enzymes were at least partially or even totally degraded within the first hour after addition (partially degraded means a significant reduction of the intensity of all or at least some of the silver-stained protein bands, although they are still visible). Cellulase was degraded completely in all digester supernatants. The enzymes of Optimase were destroyed partly or totally by all natural enzymes present in the supernatants of tested digesters. The enzymes present in Biogasverstärker were degraded partly in all reactors except for NG10 and $\mathrm{EvaH}$, where they were degraded totally. With the exception of digester EvaM and EvaH, where the polypeptide pattern in MethaPlus could not be distinguished from the natural set of enzymes, in E2 and NG10, a partial degradation of the enzymes could be detected. The proteins in Viscozyme were completely degraded in E2 and NG10 and partially degraded in EvaH and EvaM. In summary, whenever an analyzable result was obtained, a complete or at least a partial degradation of the added enzyme mixtures was obvious in all tested enzymedigester combinations within the first hour.

\subsection{Decay meter and stability of enzymes}

Degradation kinetics was performed to investigate the stability of added enzymes or enzyme mixtures. In these experiments,
Fig. 3 Time-dependent conversion of additionally added enzymes: $X$-axis: digester and time of incubation (s); Y-axis: concentration of free protein measured by Bradford test $(\mu \mathrm{g} /$ $\mu \mathrm{l})$

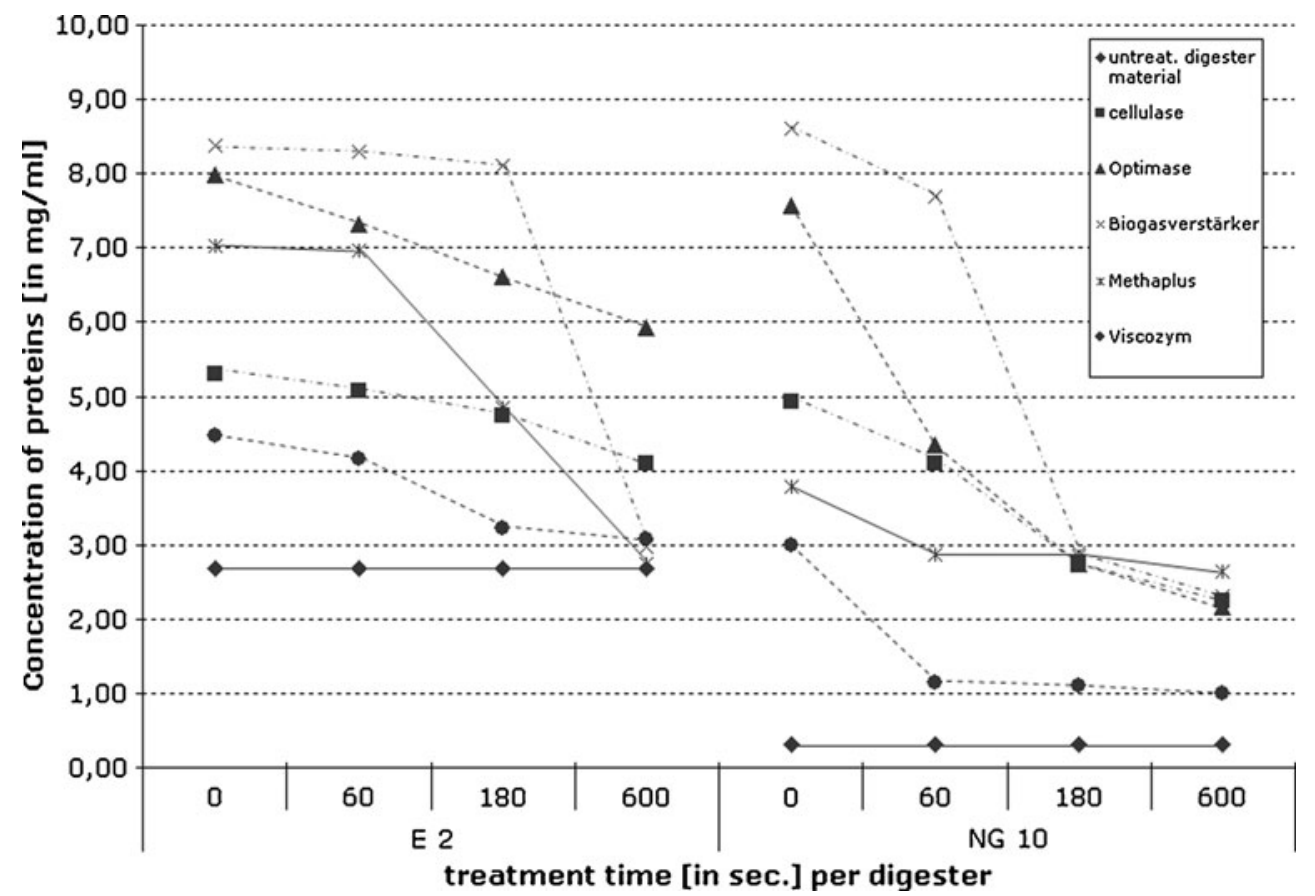


the enzymes were added to the supernatants of the different digester systems in at least 20-fold higher concentrations than suggested by the manufacturer to follow the decay of the added enzymes properly (although the addition of such concentrations is far above economic considerations). A time-related measurement of free total protein in cell- and particle-free supernatants of the four digesters showed a significant, if not complete, decay of all added enzymes/enzyme mixtures within $10 \mathrm{~min}$ (Fig. 3), while the protein content in the biomass of the reactor without the addition of enzymes was stable during the experiment (Fig. 3, blue lines).

\subsection{Viscosity}

Test series using digester materials containing added enzyme mixtures as recommended, as well as in tenfold dose (Fig. 4a, b), were carried out to analyze a possible change in the viscosity of the digestates. The tests which were carried out with the recommended concentrations of added enzymes did not show any differences compared with those in untreated samples (data not shown). However, after addition of a tenfold concentration of additives, either an increase (e.g., Viscozyme) or a decrease in the viscosity of the digestates could be observed (e.g., Biogasverstärker) (Fig. 4b), indicating an effect on the material.

\section{Discussion}

Effects of existing native enzymes in digestates of several biogas facilities on externally added enzyme mixtures were examined within this study. Continuous-fermentation tests
Fig. 4 Determination of viscosity of the digester material after 15 min on a metal ramp (inclination $38^{\circ}$ ), viewed from top to bottom: a propagation of the different digester materials after treatments with cellulase, Optimase, Biogasverstärker, MethaPlus, and Viscozyme. Black=material from fermenter $\mathrm{E} 2$, diagonally striped $=$ material from EvaH; horizontally striped $=$ material from EvaM,

dotted $=$ material from NG10. b

Running test of material from

EvaM: from left to right, control (untreated) (1), digester material treated with cellulase (2), Optimase (3), Biogasverstärker (4), MethaPlus (5), and Viscozyme (6)
A
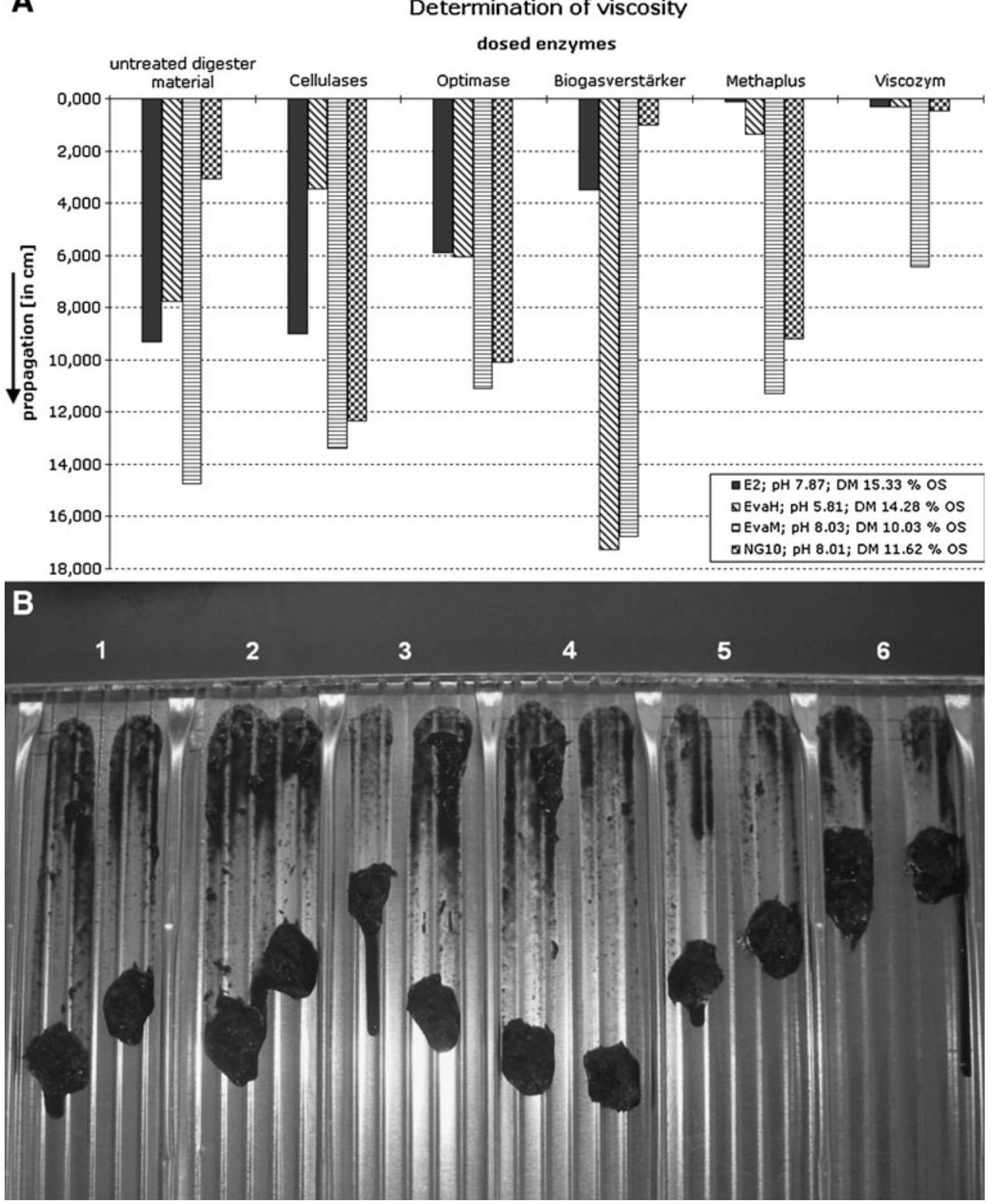
showed no increased activity in biological conversion by addition of these external enzymes mixtures. SDS-PAGE demonstrated that under these experimental conditions the enzymes were partially or totally degraded after $1 \mathrm{~h}$ (in some cases, already after a few minutes) in the presence of the digester materials. Even the use of various inhibitors to stabilize the added enzyme mixtures did not enhance their stability or activity. The analyses of enzyme degradation demonstrated an extremely short durability of the added enzyme mixtures, when brought into contact with natural extracellular enzymes of anaerobic digesters. Therefore, there is no evidence for a long-term stability of externally added enzymes. By analyzing the viscosity of the digester material supplemented with different enzyme mixtures, no effects could be obtained using the recommended concentration. After addition of a tenfold overdose of enzymes, evidence on degradation of digester material (measured by an increase or a decrease in the viscosity) was observed. However, such concentrations are far away from a commercial implementation.

As documented by SDS-PAGE analysis, pure cellulases were degraded totally in all tested fermenters. All other enzyme mixtures were either completely or at least partly degraded within $1 \mathrm{~h}$. Furthermore, differences were obvious, depending on the different digesters. The natural enzymes of digester NG10 degraded the added enzymes effectively while degradation was lower in the biomass of digester EvaM. The addition of inhibitors could not improve long-term activity of enzymes. Therefore, the present data indicate a low stability of added exoenzymes.

Analyses of protein stability by Bradford test were used to determine the actual enzyme stability. Direct comparison of digester systems and added enzyme mixtures showed a time-related reduction in concentration of free proteins within incubation time. Particularly, biomass in digester EvaH showed a very high degradation rate. Thus, it can be assumed that added enzymes were metabolized as substrate in that case. In natural systems, the hydrolytic enzymes may be either produced permanently by the corresponding microbes or, and this is at present a more speculative point, may even be protected by being bound (covalently) to the cell surface, leading to a more or less constant amount of hydrolytic enzymes in the digester.

Overdosing of externally added enzyme mixtures in individual digester systems demonstrated a slight effect by increasing or decreasing the viscosity of digestates. This was especially observed in the digesters EvaM and NG10. Since both fermentation units reflect mainly downstream processes in biogas production (acetogenesis and methanogenesis), these results indicate that still significant amounts of undigested material is available in these steps. Therefore, additional degradation by primary hydrolysis activities could significantly enhance the production of biogas.
Nevertheless, degradation of added enzymes was also observed in these digesters, resulting in an uneconomic mode of operation in the corresponding facilities.

Considering all results described in this report, it seems that the addition of enzymes and enzyme mixtures does not improve biological conversion of substrates within balanced anaerobic processes in an economic range and is therefore inadvisable. Subsequently, this study may serve as a starting point for detailed investigations concerning halflife periods of external enzymes.

\section{References}

1. Weiland P (2009) Biogas production: current state and perspectives. Appl Microbiol Biotechnol. doi:10.1007/s00253-009-2246-7

2. Amtsblatt der Europäischen Union (2009) http://eur-lex.europa. eu/LexUriServ/LexUriServ.do?uri=OJ:L:2009:140:0016:0062: DE:PDF. Accessed 20 October 2009

3. Fehrenbach H, Giegrich J, Reinhardt G, Sayer U, Gretz M, Lanje K, Schmitz J (2008) Kriterien einer nachhaltigen Bioenergienutzung im globalen Maßstab. UBA-Forschungsbericht 206:41-112

4. Bundesministerium für Umwelt, Naturschutz und Reaktorsicherheit (BMU) (2008) Biogas und Umwelt, Ein Überblick. Baier Digitaldruck $\mathrm{GmbH}$, Berlin

5. Romano RT, Zhang R, Teter S, McGarvey JA (2009) The effect of enzyme addition on anaerobic digestion of Jose tall wheat grass. Bioresour Technol. doi:10.1016/j.biortech.2008.12.065

6. Akao T, Mizuki E, Saito H, Okumura S, Murao S (1992) The methane fermentation of Citrus unshiu peel pretreated with fungus enzymes. Bioresour Technol 41:35-39

7. Sonakya V, Raizada N, Kalia V (2001) Microbial and enzymatic improvement of anaerobic digestion of waste biomass. Biotechnol Lett 23:1463-1466

8. Higgins G, Swartzbaugh J (1986) Enzyme addition to the anaerobic digestion of municipal wastewater primary sludge. USEPA Water Engineering Research Laboratory, Office of Research and Development, Cincinnati, EPA/600/2-86/084

9. Nagle N, Rivard C, Adney W, Himmel M (1992) Efficacy of hydrolytic enzyme addition and thermochemical pretreatments for increased secondary anaerobic digestion of treated municipal sewage sludges. Appl Biochem Biotechnol 34(35):737-750

10. Rintala J, Ahring B (1994) Thermophilic anaerobic digestion of source-sorted household solid waste: the effects of enzyme additions. Appl Microbiol Biotechnol 40:916-919

11. Vavilin VA, Fernandez B, Palatsi J, Flotats X (2007) Hydrolysis kinetics in anaerobic degradation of particulate organic material: an overview. Waste Manag 28:939-951

12. Gerhard M, Pelenc V, Bauml M (2007) Application of hydrolytic enzymes in the agricultural biogas production: results from practical applications in Germany. Biotechnol J 2:1481-1484

13. Fachagentur Nachwachsende Rohstoffe e.V., Gülzow (2006) Handreichung Biogasgewinnung und -nutzung. ISBN 3-00-014333-5

14. Bradford MM (1976) A rapid and sensitive method for the quantitation of microgram quantities of protein utilizing the principle of protein-dye binding. Reproduction research laboratories, department of biochemistry, University of Georgia, Athens, Georgia 30602. Anal Chem 72:248-254

15. Schägger H, von Jagow G (1987) Tricine-sodium dodecyl sulfate-polyacrylamide gel electrophoresis for the separation of proteins in the range from 1 to $100 \mathrm{kDa}$. Anal Biochem 166:368 379 